\title{
NISBAH BERAT DAUN DAN LUAS DAUN SPESIFIK TANAMAN SAWI AKIBAT PEMBERIAN PUPUK ORGANIK DI TANAH GAMBUT KOTA PALANGKA RAYA
}

\author{
DJOKO EKO HADI SUSILO
}

\author{
Dosen Program Studi Agroteknologi Fakultas Pertanian dan Kehutanan \\ Universitas Muhammadiyah Palangkaraya \\ e-mail : masdjoko_ns@yahoo.co.id
}

\begin{abstract}
The purpose of this research is to know and analyze the weight area ratio and spesific leaf area mustard green on the effect of organic fertilizer PETROGANIK on peat soil in Palangka Raya from January to March 2014 in Panarung, Palangka Raya.

This experiment used single treatment with randomized complete design, each treatment was repeated ten times. The treatment consist of single factor is dose of giving organic fertilizer PETROGANIK $(P O)$ in five levels : $P O_{1}=200 \mathrm{~kg} \mathrm{ha}^{-1}, P O_{2}=400 \mathrm{~kg} \mathrm{ha}^{-1}, P O_{3}=600 \mathrm{~kg} \mathrm{ha}^{-1}, P O_{4}=800 \mathrm{~kg} \mathrm{ha}$ and $P O_{5}=1.000 \mathrm{~kg} \mathrm{ha}^{-1}$.Variable respons of this research is high plant, number of leaf, leaf area, weight area ratio, spesific leaf area, and fresh yield of mustard green on 28 days after planting.

The experiment resulted, showed that organic fertilizer PETROGANIK non significant to high plant, number of leaf, leaf area, weight area ratio and spesific leaf area but significant and can increase fresh yield of mustard green. Although organic fertilizer PETROGANIK non significant to weight area ratio and spesific leaf area mustard green, but its an alternative variable to descripting plant growth and correlation with fresh yield of mustard green. Aplication $1.000 \mathrm{~kg} \mathrm{ha}^{-1}$ organic fertilizer PETROGANIK is the best treatment to increase growth plant and yield mustard green on peat soil.
\end{abstract}

Keywords: weight area ratio, spesific leaf area, organic fertilizer, PETROGANIK, mustard green, peat soil

\begin{abstract}
ABSTRAK
Penelitian ini bertujuan untuk mengetahui dan menganalisis nisbah berat daun dan luas daun spesifik tanaman sawi (Brassica juncea L.) akibat pemberian pupuk organik PETROGANIK di tanah gambut Kota Palangka Raya. Penelitian ini dilaksanakan pada bulan Januari-Maret 2014 di Kelurahan Panarung, Kota Palangka Raya.

Perlakuan satu faktor menggunakan Rancangan Acak Lengkap dengan 10 (sepuluh) kali pengulangan berupa pemberian pupuk organik PETROGANIK (PO) yang terdiri dari 5 taraf dosis, yaitu : $\mathrm{PO}_{1}=200 \mathrm{~kg} \mathrm{ha}^{-1} ; \mathrm{PO}_{2}=400 \mathrm{~kg} \mathrm{ha}^{-1} ; \mathrm{PO}_{3}=600 \mathrm{~kg} \mathrm{ha}^{-1} ; \mathrm{PO}_{4}=800 \mathrm{~kg} \mathrm{ha}^{-1} ;$ dan $\mathrm{PO}_{5}=1.000 \mathrm{~kg} \mathrm{ha}^{-1}$. Pengamatan dilakukan terhadap tinggi tanaman $(\mathrm{cm})$; jumlah daun (daun); luas daun $\left(\mathrm{cm}^{2}\right)$, berat segar panen $(\mathrm{g})$, nisbah berat daun $\left(\mathrm{cm}^{2} \mathrm{~g}^{-1}\right)$; dan luas daun spesifik $\left(\mathrm{cm}^{2} \mathrm{~g}^{-1}\right)$. Analisis pertumbuhan luas daun, nisbah berat daun dan luas daun spesifik menggunakan metode Sitompul dan Guritno (1995).

Hasil penelitian ini menunjukkan bahwa pemberian pupuk organik tidak berpengaruh terhadap tinggi tanaman, jumlah daun, luas daun, nisbah berat daun, dan luas daun spesifik, tetapi berpengaruh sangat nyata meningkatkan berat segar panen umur 28 hari setelah tanam.

Meskipun tidak berpengaruh terhadap nisbah berat daun dan luas daun spesifik, namun keduanya menjadi alternatif variabel pengamatan yang penting karena lebih menggambarkan pertumbuhan tanaman dan berhubungan dengan berat segar saat panen. Penggunaan pupuk organik PETROGANIK dosis 1.000 $\mathrm{kg} \mathrm{ha}^{-1}\left(\mathrm{PO}_{5}\right)$ merupakan perlakuan yang lebih baik dalam mendukung pertumbuhan dan hasil tanaman sawi.
\end{abstract}

Kata kunci : nisbah berat daun, luas daun spesifik, pupuk organik, PETROGANIK, sawi, tanah gambut 


\section{PENDAHULUAN}

Tanaman sawi (Brassica juncea L.) termasuk salah satu sayuran yang gemar dikonsumsi oleh masyarakat Indonesia. Hal ini terlihat dari hadirnya sayuran sawi di pasar-pasar tradisional maupun modern sehari-harinya sebagai sayuran yang cukup bergizi bagi masyarakat. Sawi juga memiliki beberapa manfaat yang baik untuk kesehatan karena kandungan gizinya cukup tinggi dan beragam berupa protein, lemak, karbohidrat, kalsium, fosfor, zat besi, Vitamin A, Vitamin B, dan Vitamin C. Setiap $100 \mathrm{~g}$ daun segar tanaman sawi mengandung vitamin A $6.460 \mathrm{SI}$, vitamin B 0,09 $\mathrm{mg}$ dan vitamin C $120 \mathrm{mg}$ (Haryanto, Suhartati dan Rahayu, 2002).

Mengingat kebutuhan masyarakat terhadap sayuran sawi sehari-harinya yang cukup tinggi, maka memungkinkan tanaman sawi potensial diteliti dan dibudidayakan menjadi sayuran yang komersial dengan prospek pasar yang lebih baik berupa produksi dan produktivitasnya yang tinggi. Sebagai upaya meningkatkan produksi dan produktivitas sawi, di Kalimantan Tengah baru dalam tahap memiliki produksi mencapai 1,4308 ton dengan luas panen 671 ha dan produktivitasnya 2,132 ton ha-1 (Badan Pusat Statistik, 2012). Hal ini yang memungkinkan berbagai teknik budidaya dan penelitian dilakukan untuk meningkatkan produksi maupun produktivitasnya, diantarnya dengan pemberian beberapa perlakuan yaitu formula EKD dan pupuk kandang kotoran ayam (Saipin, 2004), bokashi (Bahri, 2004), pupuk Supreme Organik (Penie, 2012), abu serbuk gergaji (Maelanhidayah, 2013a), pupuk gambut dan nitrogen (Maelanhidayah, 2013 ${ }^{b}$.
Salah satu pupuk yang berguna untuk menggemburkan dan menyuburkan tanah, adalah pupuk organik PETROGANIK, yang memperkaya hara makro dan mikro dalam tanah karena mengandung C-organik yang tinggi 12,5\% dengan $\mathrm{C} / \mathrm{N}$ ratio $10-25$ dan pHnya 4-8. Pupuk ini berbentuk granular yang siap dan mudah dalam aplikasi sehingga cepat membantu meningkatkan keremahan tanah. Pupuk ini juga dianjurkan untuk tanaman hortikultura (termasuk jenis sayuran) dengan harapan mendukung kesuburan tanah maupun pertumbuhan tanaman sayuran secara cepat (Anonim, 2013).

Seiring beberapa pengamatan-pengamatan penelitian pada beberapa perlakuan yang pernah diberikan terhadap tanaman sawi di tanah gambut maupun jenis tanaman lainnya, sering terjadi variasi hasil pengamatan maupun gambaran kemampuan meningkatkan pertumbuhan dan hasil tanaman sawi. Terkadang beberapa pengamatan berupa tinggi tanaman, jumlah daun, luas daun, panjang daun, lebar daun tidak siginifikan, bahkan terhadap berat segar panennya pun menunjukkan ketidaksiginifikan juga. Tetapi di lain waktu juga terjadi hasil penelitian hanya signifikan terhadap berat segar panennya saja. Hal ini perlu dicermati bahwa penting juga mengamati analisis pertumbuhan tanaman berupa biomassa tanaman yang bisa dilakukan terintegrasi dengan mengamati harga satuan daun. Sitompul dan Guritno (1995) menyatakan bahwa daun merupakan organ tempat utama proses fotosintesis yang digunakan memproduksi biomassa tanaman.

Berdasarkan kondisi tersebut, budidaya tanaman sawi yang relatif berumur cepat dibutuhkan perlakuan dan pengamatan yang bisa 
menggambarkan pertumbuhannya. Pupuk organik PETROGANIK diharapkan dapat mengkondisikan media tanam tanah gambut menjadi lebih baik dan analisis pertumbuhan berupa nisbah berat daun (NBD) dan luas daun spesifik (LDS) tanaman sawi dapat memberikan gambaran pertumbuhan yang akurat sekaligus diharapkan dapat menggambarkan peningkatan pertumbuhan dan hasil tanaman sawi di tanah gambut. Oleh kerena itu, tujuan penelitian ini adalah untuk mengetahui dan menganalisis nisbah berat daun dan luas daun spesifik tanaman sawi (Brassica juncea L.) akibat pemberian pupuk organik PETROGANIK di tanah gambut.

\section{METODOLOGI}

Penelitian dilaksanakan pada bulan Januari-Maret 2014 di Kelurahan Panarung, Kecamatan Pahandut, Kota Palangka Raya. Bahan yang digunakan dalam penelitian ini yaitu pupuk organik PETROGANIK, kapur dolomit, benih dan bibit tanaman sawi varietas Tosakan, media tanah gambut dan air. Sedangkan peralatan yang digunakan yaitu cetok, polybag besar (ukuran $40 \times 35 \mathrm{~cm}$ ), gelas penyiram, pisau cuter, oven tanaman, neraca analitik, kamera, kertas milimeter blok, amplop karton, penggaris, kalkulator, laptop komputer, dan alat tulis.

Rancangan perlakuan berupa satu faktor perlakuan yang diulang 10 (sepuluh) kali. Perlakuan berupa pemberian pupuk organik PETROGANIK (PO) yang terdiri dari 5 taraf dosis, yaitu : $\mathrm{PO}_{1}=200 \mathrm{~kg} \mathrm{ha-1} ; \mathrm{PO}_{2}=400 \mathrm{~kg} \mathrm{ha}^{-1}$; $\mathrm{PO}_{3}=600 \mathrm{~kg} \mathrm{ha}{ }^{-1} ; \mathrm{PO}_{4}=800 \mathrm{~kg} \mathrm{ha}^{-1} ;$ dan $\mathrm{PO}_{5}=1.000 \mathrm{~kg}$ ha-1 menggunakan rancangan lingkungan Rancangan Acak Lengkap. Pengamatan dilakukan dilakukan terhadap tinggi tanaman (cm); jumlah daun (daun); luas daun $\left(\mathrm{cm}^{2}\right)$. Pengukuran berat kering daun dan berat kering tanaman dilakukan untuk mengamati nisbah berat daun $\left(\mathrm{cm}^{2} \mathrm{~g}^{-1}\right)$; dan luas daun spesifik $\left(\mathrm{cm}^{2} \mathrm{~g}^{-1}\right)$.

Analisis pertumbuhan luas daun, nisbah berat daun dan luas daun spesifik menggunakan metode Sitompul dan Guritno (1995). Data hasil pengamatan dianalisis menggunakan analisis ragam (Uji F) pada taraf $\alpha=0,05$ dan 0,01 . Uji lanjut berupa uji beda rataan yang digunakan adalah uji Beda Nyata Jujur taraf 0,05 (Mattjik dan Sumertajaya, 2002).

\section{HASIL DAN PEMBAHASAN}

\section{Hasil Pengamatan}

Hasil pengamatan berupa pertumbuhan dan hasil panen tanaman sawi menunjukkan bahwa setelah dilakukan analisis ragam ternyata pemberian pupuk organik PETROGANIK tidak berpengaruh terhadap pertumbuhan tinggi tanaman, jumlah daun dan luas daun. Pemberian pupuk organik PETROGANIK juga tidak berpengaruh terhadap nisbah berat daun dan luas daun spesifik, namun mempengaruhi sangat nyata terhadap hasil berat segar panen sawi pada umur 28 hari setelah tanam (hst). Hasil uji rataan pertumbuhan dan hasil tanaman sawi disajikan pada Tabel 1.

Berdasarkan hasil analisis ragam maupun hasil uji lanjut rataan pertumbuhan dan hasil tanaman sawi pada Tabel 1 menunjukkan bahwa pertumbuhan tanaman sawi setelah mendapatkan perlakuan pemupukan organik PETROGANIK, nampaknya bervariasi (tinggi tanaman, jumlah daun, luas daun, nisbah berat daun, luas daun 
Tabel 1. Hasil uji rataan pertumbuhan dan hasil tanaman sawi umur 28 hst akibat pemberian pupuk organik PETROGANIK di tanah gambut

\begin{tabular}{|c|c|c|c|c|c|c|}
\hline \multirow{2}{*}{ Pengamatan } & \multicolumn{5}{|c|}{ Pupuk organik PETROGANIK } & \multirow{2}{*}{$\mathrm{BNJ}_{5} \%$} \\
\hline & $\mathrm{PO}_{1}$ & $\mathrm{PO}_{2}$ & $\mathrm{PO}_{3}$ & $\mathrm{PO}_{4}$ & $\mathrm{PO}_{5}$ & \\
\hline a. Tinggi tanaman $\left(\mathrm{cm} \mathrm{tan}^{-1}\right)$ & 35,45 & 36,05 & 35,60 & 35,65 & 35,85 & - \\
\hline b. Jumlah daun (daun $\tan ^{-1}$ ) & 9,60 & 9,80 & 9,80 & 9,90 & 10,10 & - \\
\hline c. Luas daun $\left(\mathrm{cm}^{2} \tan ^{-1}\right)$ & $1.038,62$ & $1.059,32$ & $1.059,65$ & $1.062,43$ & $1.064,68$ & - \\
\hline d. Nisbah berat daun $\left(\mathrm{g} \mathrm{g}^{-1}\right)$ & 0,4551 & 0,4785 & 0,4790 & 0,4846 & 0,4861 & - \\
\hline e. Luas daun spesifik $\left(\mathrm{cm}^{2} \mathrm{~g}^{-1}\right)$ & 326,97 & 313,07 & 313,05 & 294,61 & 290,86 & - \\
\hline f. Berat segar panen $\left(\mathrm{g} \mathrm{tan}^{-1}\right)$ & 91,12 a & $95,80^{a}$ & 96,24 a & 96,85 a & $103,69 \mathrm{~b}$ & 6,29 \\
\hline
\end{tabular}

Keterangan : Nilai rataan yang diikuti huruf yang sama pada pengamatan berat segar panen menunjukkan tidak berbeda menurut uji BNJ 5\%.

spesifik) namun hanya pada hasil tanaman sawi berupa berat segar panen per tanaman yang memiliki perbedaan secara nyata, yaitu perlakuan $1.000 \mathrm{~kg} \mathrm{ha}^{-1}$ PETROGANIK (PO5) memberikan hasil yang berbeda nyata dengan perlakuan lainnya $\left(\mathrm{PO}_{1}, \mathrm{PO}_{2}, \mathrm{PO}_{3}\right.$ dan $\left.\mathrm{PO}_{4}\right)$.

Pemberian pupuk organik PETROGANIK ke dalam tanah gambut ini sedemikian rupa juga menunjukkan perbaikan sifat tanah gambut sehingga kesuburan tanah gambut menjadi lebih baik dan memberikan lingkungan tumbuh yang membaik pula bagi tanaman sawi. Kandungan hara makro dan mikro pada pupuk organik PETROGANIK secara khusus melepas secara bertahap sehari-harinya sehingga menambah neraca hara dalam tanah gambut sehingga menyediakan bagi kebutuhan tanaman sawi hingga tanaman sawi mampu dipanen umur 28 hst. Kandungan hara makro dan mikro tersebut diserap dan dimanfaatkan tanaman sawi untuk pertumbuhannya sehingga secara akumulatif mendukung hasil panen, meskipun hasil panen ini masih sangat rendah dibandingkan potensi varietasnya yang berat segar panennya mampu mencapai $400 \mathrm{~g} \mathrm{tan}^{-1}$ (Anonim, 2006).

\section{Pembahasan}

\section{Nisbah Berat Daun (NBD)}

Berdasarkan Tabel 1, menunjukkan bahwa secara nyata dan efektif terjadi penyediaan hara makro dan mikro bagi tanaman sawi akibat pemberian pupuk organik PETROGANIK sehingga dengan meningkatnya pupuk organik PETROGANIK yang diberikan maka meningkat pula nilai NBD pada pertumbuhan tanaman sawi. Hal ini menunjukkan bahwa terjadi alokasi bahan kering yang membaik kepada masing-masing perlakuan akibat peningkatan pupuk organik PETROGANIK yang diberikan.

Tabel 1 juga menunjukkan bahwa pertumbuhan daun tanaman sawi pada masingmasing perlakuan $\mathrm{PO}_{1}$ sampai $\mathrm{PO}_{5}$ yang ditunjukkan oleh bervariasinya nilai NBD. Ini merupakan gambaran sederhana, bahwa dengan diberikan pemupukan $1.000 \mathrm{~kg} \mathrm{ha}^{-1}\left(\mathrm{PO}_{5}\right)$ nampaknya tanaman sawi pada umur 28 hst memiliki NBD sebesar 0,4861 (g g $\left.\mathrm{g}^{-1}\right)$, artinya alokasi bahan kering ke daun sebesar nilai tersebut dibanding alokasi bahan kering ke seluruh tubuh tanaman (berat kering tanaman). Apabila kita perhatikan pada perlakuan pemupukan $200 \mathrm{~kg} \mathrm{ha}^{-1}\left(\mathrm{PO}_{1}\right)$ nampaknya 
tanaman sawi pada umur 28 hst hanya memiliki NBD sebesar 0,4551 $\left(\mathrm{g} \mathrm{g} \mathrm{g}^{-1}\right)$ dan ini lebih rendah dalam menunjukkan adanya alokasi bahan kering tersebut. Kondisi ini sesuai dengan yang dijelaskan oleh Sitompul dan Guritno (1995), bahwa NBD merupakan perbandingan antara berat daun dengan berat total tanaman.

Selain itu dengan mengamati NBD ini (Tabel 1), nampaknya lebih menggambarkan pertumbuhan tanaman sawi dibandingkan pengamatan lainnya (tinggi tananaman maupun jumlah daun) karena nilai NBD yang kita ketahui setelah pengamatan sebetulnya menjadi bagian penting bahwa terjadi pembagian karbohidrat sebagai investasi modal bagi organ produktif dalam tubuh tanaman. Mengetahui nilai NBD tanaman sawi ini sepertinya menjadi lebih bijaksana dalam mempelajari penggambaran pertumbuhan. Hal ini senada dengan yang dijelaskan oleh Sitompul dan Guritno (1995) bahwa pembagian karbohidrat ke daun sangat menentukan perkembangan tanaman dalam siklus hidupnya, dan bisa diketahui dengan menganalisis nilai nisbah berat daunnya.

\section{Luas Daun Spesifik (LDS)}

Berdasarkan Tabel 1, menunjukkan bahwa pemberian pupuk organik PETROGANIK telah efektif meningkatkan pertumbuhan daun bagi tanaman sawi, dan terlihat meningkatnya dosis pupuk organik PETROGANIK yang diberikan maka meningkat pula pertumbuhan daun tanaman sawi yang diindikasikan oleh semakin menurunnya nilai LDS. Hal ini menunjukkan bahwa selain terjadi alokasi bahan kering yang membaik pada masing-masing perlakuan juga terjadi pertumbuhan daun dengan baik.
Tabel 1 juga memperlihatkan bahwa selain meningkatnya nilai NBD pada masing-masing perlakuan $\mathrm{PO}_{1}$ sampai $\mathrm{PO}_{5}$ merupakan kelanjutan proses pertumbuhan daun dari alokasi karbohidrat yang diterima masing-masing daun tanaman. Sebagai pengamatan yang spesifik, maka LDS memberikan gambaran yang sederhana pula bahwa dengan diberikan pemupukan $1.000 \mathrm{~kg}$ ha${ }^{1}\left(\mathrm{PO}_{5}\right)$ ternyata tanaman sawi pada umur $28 \mathrm{hst}$ memiliki LDS sebesar 290,86 $\left(\mathrm{cm}^{2} \mathrm{~g}^{-1}\right)$, artinya alokasi bahan kering yang diterima oleh daun mampu digunakan untuk pertumbuhan daun. Sedangkan perlakuan pemupukan $200 \mathrm{~kg} \mathrm{ha}^{-1}$ ( $\left.P O_{1}\right)$ nampaknya memiliki LDS sebesar 326,97 $\left(\mathrm{cm}^{2} \mathrm{~g}^{-1}\right)$. Kondisi ini, mencerminkan pertumbuhan luas daun tanaman terjadi dengan baik, namun juga menghasilkan informasi ketebalan daun tanaman sawi yang mampu terbentuk oleh pertumbuhan tersebut. Diketahuinya LDS ini, merupakan penggambaran efisiensi pembentukan luas daun tanaman sawi per satuan karbohidrat yang tersedia. Hal ini sesuai dengan penjelasan Sitompul dan Guritno (1995) bahwa luas daun spesifik dapat mempelajari efisiensi pembentukan luas daun per satuan karbohidrat, yaitu merupakan pembagian antara luas daun dengan berat daun.

Apabila dilihat dari Tabel 1, informasi ketebalan daun tanaman sawi sekaligus juga dapat diketahui bahwa perlakuan pemberian pupuk organik PETROGANIK ini memberikan efek yang baik terhadap LDS tersebut. Terlihat bahwa pemupukan $1.000 \mathrm{~kg} \mathrm{ha}^{-1}\left(\mathrm{PO}_{5}\right)$ ternyata memiliki LDS sebesar 290,86 $\left(\mathrm{cm}^{2} \mathrm{~g}^{-1}\right)$, yang artinya daunnya lebih tebal dibanding perlakuan lainnya. Informasi ini juga menggambarkan bahwa dengan bervariasinya ketebalan daunnya maka 
diduga menjadi penentu berpengaruhnya perlakuan yang diberikan terhadap berat segar panen yang dihasilkan sehingga setelah data hasil pengamatan dianalisis ragam menunjukkan pengaruh yang sangat nyata. Selain itu, dengan diketahuinya ketebalan daun sawi tersebut, maka membimbing mendapatkan informasi tentang unit organella fotosintesis pada daun sawi yang mempunyai hubungan yang pasti dengan adanya proses fotosintesis oleh tanaman sawi tersebut. Kondisi ini sesuai dengan yang dijelaskan oleh Sitompul dan Guritno (1995) bahwa daun yang tebal akan mempunyai kloroplas yang lebih banyak per satuan luas daunnya sehingga akan mempunyai kapasitas mengintersepsi energi cahaya dan mereduksi $\mathrm{CO}_{2}$ yang lebih tinggi daripada daun yang tipis. Oleh karena itu, sebagai fakta pertumbuhan tanaman, pengamatan LDS sebenarnya tanpa dianalisis ragam (uji F) dan diuji lanjut menggunakan BNJ5\% pun sudah cukup memberikan gambaran pertumbuhan tanaman, karena LDS merupakan salah satu informasi pertumbuhan daun sekaligus tentang ketebalan daun yang akhirnya mengandung informasi berupa pertumbuhan organ daun sebagai organ fotosintesis yang pengaruhnya terhadap laju fotosintesis.

Apabila memperhatikan dosis penggunaan pupuk organik PETROGANIK dan pertumbuhan maupun hasil panennya (Tabel 1), maka aplikasi tertinggi pemupukan pada penelitian ini yaitu dosis $1.000 \mathrm{~kg} \mathrm{ha}^{-1}\left(\mathrm{PO}_{5}\right)$ masih merupakan setengah dosis anjuran untuk tanaman hortikultura (Anonim, 2013). Peningkatan dosis pemupukan perlu dilakukan dan diharapkan nilai NBD dan LDS maupun tebal daun bisa ditingkatkan pada pertumbuhan tanaman sawi.
Berdasarkan Tabel 1 juga menunjukkan bahwa pemberian pupuk organik PETROGANIK sampai $1.000 \mathrm{~kg} \mathrm{ha}^{-1}\left(\mathrm{PO}_{5}\right)$ selain menunjukkan pertumbuhan yang lebih baik secara umum, dan berbeda nyata memiliki hasil panen berat segar dibandingkan perlakuan lainnya, meskipun tidak pada variabel pengamatan lainnya. Hal ini menunjukkan bahwa penggunaan pupuk organik PETROGANIK minimal diberikan sebesar 1.000 $\mathrm{kg} \mathrm{ha}^{-1}$ untuk budidaya tanaman sawi di tanah gambut.

\section{KESIMPULAN DAN SARAN}

Kesimpulan penelitian ini adalah :

a. Pemberian pupuk organik PETROGANIK tidak berpengaruh terhadap tinggi tanaman, jumlah daun, luas daun, nisbah berat daun, dan luas daun spesifik, tetapi berpengaruh sangat nyata meningkatkan berat segar panen umur 28 hari setelah tanam.

b. Analisis pertumbuhan tanaman berupa nisbah berat daun dan luas daun spesifik menjadi alternatif variabel pengamatan yang penting karena lebih menggambarkan pertumbuhan dan berhubungan erat dengan berat segar saat panen.

c. Penggunaan pupuk organik PETROGANIK dosis $1.000 \mathrm{~kg}$ ha $^{-1}$ (PO5) merupakan perlakuan yang lebih baik dalam mendukung pertumbuhan dan hasil tanaman sawi di tanah gambut.

Hasil penelitian menyarankan, bahwa :

a. Setiap penelitian tanaman sawi, disarankan mengamati harga satuan daun, termasuk karakteristik daun berupa nisbah berat daun dan luas daun spesifik. 
b. Meningkatkan pemberian pupuk organik PETROGANIK lebih dari $1.000 \mathrm{~kg} \mathrm{ha-1}$ untuk mendukung peningkatan hasil panen segar tanaman sawi.

\section{UCAPAN TERIMA KASIH}

Ucapan terima kasih disampaikan kepada Laboratorium Fakultas Pertanian dan Kehutanan Universitas Muhammadiyah Palangkaraya yang telah memfasilitasi dan mendukung pelaksanaan analisis pertumbuhan tanaman sawi dengan lancar dan menyenangkan bagi peneliti.

\section{DAFTAR PUSTAKA}

Anonim, 2006. Sawi Varietas TOSAKAN. East West Seed Indonesia, Cap Panah Merah.

Anonim, 2013. Brosur Produk Petrokimia Gresik : Pupuk Organik PETROGANIK, Pupuk Organik Super. PT. Petrokimia Gresik. Gresik.

Badan Pusat Statistik, 2012. Produksi Sawi Kalimantan Tengah Tahun 2011. Badan Pusat Statistik Republik Indonesia. http://www.bps.go.id. Diakses pada tanggal 12 Desember 2012.

Bahri, S., 2004. Respon Tanaman Sawi (Brassica juncea L). Terhadap Pemberian Beberapa Macam Bokashi Pada Tanah Gambut Pedalaman. Skripsi Fakultas Pertanian. Universitas Muhammadiyah Palangka Raya. Palangka Raya.

Haryanto, E. Suhartini, T. dan Rahayu, E. 2002. Sawi dan Selada. Penebar Swadaya. Jakarta.

Maelanhidayah, N., 2013a. Pengaruh Pemberian Abu Serbuk Gergaji Terhadap Pertumbuhan dan Hasil Sawi (Brassica juncea L.) Pada Tanah Gambut Pedalaman. Laporan Praktek Lapang Fakultas Pertanian dan Kehutanan. Universitas Muhammadiyah Palangka Raya. Palangka Raya.
Maelanhidayah, N., 2013b. Pengaruh Pemberian Pugam dan Nitrogen Terhadap Pertumbuhan dan Hasil Sawi (Brassica juncea L.) Pada Tanah Gambut Pedalaman. Skripsi Fakultas Pertanian dan Kehutanan. Universitas Muhammadiyah Palangka Raya. Palangka Raya.

Mattjik, A. A. dan I.M. Sumertajaya. 2002. Perancangan Percobaan dengan Aplikasi SAS dan Minitab. Jilid I Edisi Ke-dua. IPB PRESS. Bogor.

Penie, 2012. Pengaruh Pemberian Pupuk Supreme Organik Terhadap Pertumbuhan dan Hasil Sawi (Brassica juncea L.) Pada Tanah Gambut Pedalaman. Skripsi Fakultas Pertanian dan Kehutanan. Universitas Muhammadiyah Palangka Raya. Palangka Raya.

Saipin, 2004. Pengaruh Pemberian Formula EKD Melalui Daun dan Pupuk Kandang Ayam Terhadap Pertumbuhan dan Hasil Tanaman Sawi (Brassica juncea L). Pada Tanah Podsolik Merah Kuning. Skripsi Fakultas Pertanian. Universitas Muhammadiyah Palangka Raya. Palangka Raya.

Sitompul, S.M., dan B. Guritno, 1995. Analisis Pertumbuhan Tanaman. Gadjah Mada University Press. Yogyakarta. 